\title{
Bagaimana pemasaran jasa pendidikan mempengaruhi pesantren: Efek pada aspek mutu
}

\section{Liah Siti Syarifah *}

Sekolah Tinggi Agama Islam Syamsul 'Ulum Gunungpuyuh Sukabumi

Jl. Bhayangkara No. 27-29, Gunungpuyuh, Kota Sukabumi, Jawa Barat 43123, Indonesia.

* Corresponding Author. Email: liahsitisyarifah.27@gmail.com

\section{ARTICLE INFO}

\section{Article History}

Received:

22 January 2021;

Revised:

26 April 2021;

Accepted:

3 May 2021

Available online:

3 May 2021

\section{Keywords}

manajemen

pendidikan;

mutu pesantren;

pemasaran pendidikan.

educational

management;

boarding school

quality;

educational marketing.

\begin{abstract}
Penelitian ini bertujuan menemukan pengaruh pemasaran jasa pendidikan terhadap mutu Pondok Pesantren Syamsul 'Ulum. Penelitian ini menggunakan pendekatan kuantitatif dengan metode survey. Populasi penelitian ini adalah seluruh pelanggan internal dan eksternal pesantren. Teknik cluster sampling digunakan untuk memilih responden yang terdiri dari santri, guru, pembimbing asrama dan orang tua santri dengan jumlah 220 orang. Teknik pengumpulan data dilakukan dengan angket, wawancara dan dokumentasi. Selanjutnya dilakukan analisis data dengan menggunakan statistik parametrik melalui bantuan software SPSS 25.0 melalui persamaan regresi linear sederhana, apabila nilai thitung <ttabel, maka H0 diterima, tapi apabila nilai thitung > ttabel, maka H0 ditolak. Hasil penelitian menunjukan bahwa thitung > ttabel $(10,257>1,971)$ sehingga H0 ditolak artinya terdapat pengaruh positif dan signifikan pemasaran pendidikan terhadap mutu Pondok Pesantren Syamsul 'Ulum dengan persentase sebesar 32,7\%. Berdasarkan hasil penelitian tersebut dapat disimpulkan bahwa kegiatan pemasaran pendidikan akan meningkatkan mutu Pondok Pesantren Syamsul 'Ulum. Hal tersebut berimplikasi bahwa Pondok Pesantren Syamsul 'Ulum seyogyanya memberi perhatian yang serius pada kebutuhan pengguna jasa pendidikan dan jeli melihat segmentasi dan penentuan sasaran.
\end{abstract}

This research aims to discover the effect of marketing education services on the quality of Syamsul 'Ulum Islamic Boarding School. The research populations were internal and external customers of the boarding school. Cluster sampling technique was used to select respondents consisting of students, teachers, boarding supervisors and students' parents with a total of 220 people. Data collection was conducted by questionnaire, interview and documentation techniques. Then, data were analyzed using parametric statistics through the help of SPSS 25.0 software through a simple linear regression, if the value of thitung<ttabel, therefore $\mathrm{HO}$ is accepted, but if tcount $>$ ttable, therefore $\mathrm{HO}$ is rejected. The results of research showed that tcount $>$ ttable $(10.257>1.971)$ therefore $\mathrm{HO}$ was rejected, it means that there was a positive and significant influence of education marketing on the quality of Syamsul 'Ulum Islamic Boarding School with a percentage of $32.7 \%$. Based on the results of the research, it is concluded that educational marketing activities will improve the quality of Syamsul 'Ulum Islamic Boarding School. This implies that the Syamsul Islamic Boarding School 'Ulum should give a serious attention to the needs of customers and is keen to see a segmentation and targeting.

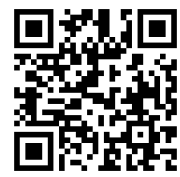

This is an open access article under the CC-BY-SA license.

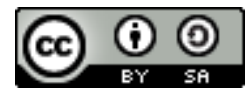

How to cite:

Syarifah, L. (2021). Bagaimana pemasaran jasa pendidikan mempengaruhi pesantren: Efek pada aspek mutu. Jurnal Akuntabilitas Manajemen Pendidikan, 9(1), 34-42. doi:https://doi.org/10.21831/jamp.v9i1.38115 


\section{PENDAHULUAN}

Saat ini dimensi mutu merupakan hal yang sangat penting, baik dalam dunia pendidikan, bisnis, maupun pemerintahan. Mutu merupakan sebuah filosofi tentang perbaikan terus menerus yang dapat memberikan seperangkat alat praksis kepada setiap institusi pendidikan dalam memenuhi kebutuhan, keinginan, juga harapan para pelanggannya saat ini dan untuk masa yang akan datang (Sallis, 2007). Lembaga pendidikan pesantren yang bermutu akan terkonstruksi dengan baik jika pesantren mampu mendesain sistem pendidikannya sesuai dengan tuntutan mutu pendidikan dewasa ini. Di sisi lain, dalam mempertahankan kualitas atau mutu sebuah institusi, perlu dibangun budaya mutu (Muhith, 2018), yaitu sistem nilai, kepercayaan, asumsi, atau norma yang berlaku, disepakati dan diikuti oleh anggota organisai sebagai perilaku, bahkan menjadi pedoman dan solusi dari berbagai masalah yang dihadapi.

Terlebih, di era globalisasi saat ini, lembaga pendidikan pesantren adalah salah satu institusi pendidikan yang menghadapi tantangan yang sangat kuat. Pada satu kondisi, pondok pesantren hadir sebagai salah satu model pendidikan asli (indigenous) di Indonesia (Mustaqiem, 2003) dan telah memiliki pengaruh besar dalam kehidupan masyarakat Indonesia (Siswanto, 2015). Di sisi lain, pondok pesantren dihadapkan pada suatu kompetisi yang tidak terelakkan. Dalam kondisi seperti ini, selain berperan sebagai agen karakter dan kultural bangsa, pondok pesantren juga harus mampu menarik minat masyarakat dengan kebutuhan yang sangat kompleks (Ali \& Fahrurrozi, 2006). Hal tersebut senada dengan gagasan dari Azyumardi Azra tentang modernisasi pesantren yang harus mampu menumbuhkan apresiasi yang sepatutnya terhadap semua perkembangan yang terjadi di masa kini dan mendatang (Bashori, 2017), menurutnya, dengan kondisi demikian, diharapkan dapat melahirkan ulama yang berwawasan luas dengan tetap mempertahankan ciri utamanya, yaitu memproduksi ulama dan pusat tafaqquh fiddien, tanpa terbawa arus globalisasi.

Dimensi "mutu" diharapkan menjawab tuntutan dan kebutuhan masyarakat yang hidup pada era global ini yang mampu melahirkan lulusan (output) yang berdaya saing tinggi dengan segala orisinalitas budaya Indonesia dan pesantren itu sendiri. Salah satu filosofi mutu yang dapat diadaptasi oleh lembaga pendidikan pesantren adalah Total Quality Management (Syarifah, 2020a). Lebih lanjut, implementasi Total Quality Management (TQM) di pesantren dilakukan dengan mengangkat "mutu" sebagai strategi usaha dengan penerapan filosofi Total Quality Management (TQM), yaitu perbaikan berkelanjutan pada seluruh aktivitas manajemen di pesantren. Pada saat yang sama, usaha yang dilakukan tersebut diorientasikan pada kepuasan pengguna layanan jasa pendidikan, dengan tentunya dilandasi nilai-nilai agama Islam (Syarifah, 2020b).

Menurut Rasmi (2014), ada beberapa manfaat mengimplementasikan Total Quality Management (TQM) dalam dunia pendidikan, yaitu sebagai berikut: memperkuat organisasi sekolah dan memberikan jalan atau arah bagi perubahan menuju kemajuan; menolong kita untuk bekerja sebagai teman dalam kelompok kerja bukan sebagai musuh; mengupayakan suatu program yang akan mengusahakan bukan hanya penanganan satu aspek saja dari pendidikan; meningkatkan partisipasi setiap orang yang terlibat dalam penyelenggaraan sekolah dan usaha masyarakat perguruan atau sekolah; mengarahkan para orang tua dan pelajar-pelajar untuk membuat saransaran untuk memajukan keadaan sekolah; mengarahkan adanya pihak yang terkait yang bertanggungjawab dalam membuat standar mutu pendidikan bagi sekolah; dan menjadikan sikap proaktif daripada bersikap reaktif terhadap sesuatu yang mempengaruhi sekolah.

Untuk mencapai pesantren yang bermutu, sebuah lembaga harus memberdayakan seluruh sumber daya yang dimilikinya (Syarifah, 2019), salah satunya adalah pemasaran (market). Pemasaran merupakan seni menciptakan permintaan, juga proses mengejar pelanggan yang ada maupun yang potensial (Kalenskaya et al., 2013). Kurangnya perhatian sebuah institusi/lembaga pada kegiatan pemasaran membuat mereka yang mengelola lembaga pendidikan tidak menyadari dan kurang mengeksploitasi peran yang dapat dimainkan promosi dalam mencapai tujuan organisasi mereka. Padahal sudah terdapat beberapa penelitian yang menemukan peran strategis pemasaran dalam peningkatan mutu pendidikan, misalnya penelitian dari Khasanah (2015) yang menemukan bahwa pemasaran jasa pendidikan merupakan strategi peningkatan mutu pendidikan yang terpenting bagi kualitas serta kemajuan taraf pendidikan pada suatu lembaga pendidikan. Lebih lanjut, Muadin (2017) menjelaskan bahwa pemasaran jasa pendidikan pesantren harus diterapkan untuk 
menciptakan budaya kualitas dalam setiap segmen dan langkahnya supaya jasa layanan pendidikan yang disiapkan benar-benar sesuai dengan kebutuhan. Sebut saja pondok pesantren Darul Falah (pondok pesantren Amtsilati), terkait dengan pemasaran jasa pendidikan untuk peningkatan mutu pesantren, pimpinannya melakukan tiga strategi, yaitu menganalisis kebutuhan riil santri sebagai calon pengguna jasa berupa produk/kitab yang benar-benar dibutuhkan, menyusun buku khulasah (ringkasan) Alfiyah yang kemudian disebut Amtsilati, dan menggunakan Amtsilati sebagai branding dalam memperkenakan lembaga pendidikan Islam dengan keunggulan berupa mudah memahami ilmu nahwu dan sharaf dalam waktu yang singkat (Mustaqim, 2018).

Pemasaran lembaga pendidikan pesantren mendapatkan momentum dengan meningkatnya animo masyarakat pada pesantren dengan kondisi banyak bermunculannya pesantren dengan program-program keunggulan tertentu demi menarik minat santri atau calon santri, ditambah lagi perkembangan teknologi dan menyusutnya batasan global yang telah meningkatkan pentingnya pemasaran untuk layanan pendidikan. Maka dari itu, penelitian ini ditujukan untuk menguji pengaruh pemasaran jasa pendidikan terhadap mutu Pondok Pesantren Syamsul 'Ulum, mengingat pemasaran bagi lembaga pendidikan (terutama pesantren) memiliki prean sentral di tengah persaingan antar pesantren yang semakin atraktif seperti sekarang.

Berdasarkan latar belakang masalah, perumusan masalah dan tujuan penelitian, maka kerangka konseptual penelitian dapat dilihat pada Gambar 1. Berdasarkan kerangka konseptual pada Gambar 1, maka hipotesis penelitian ini dapat dirumuskan menjadi hipotesis nol (H0) dan hipotesis alternatif (Ha) sebagai berikut:

H0: Tidak terdapat pengaruh dari variabel pemasaran pendidikan terhadap mutu pesantren.

Ha: Terdapat pengaruh dari variabel pemasaran pendidikan terhadap mutu pesantren.

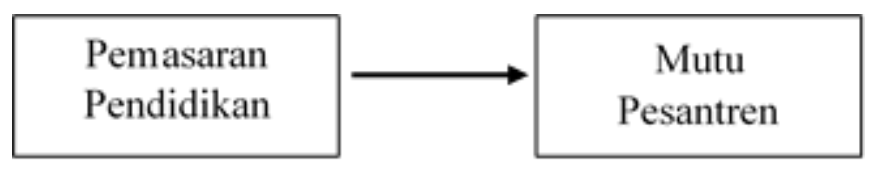

Gambar 1. Kerangka Konseptual Penelitian

Adapun kriteria keputusan yang digunakan yaitu apabila hipotesis nol (H0) diterima, maka hipotesis alternatif (Ha) ditolak, artinya tidak terdapat pengaruh dari variabel pemasaran pendidikan terhadap mutu pesantren. Demikian pula sebaliknya, jika hipotesis alternatif (Ha) diterima, maka hipotesis nol (H0) ditolak, artinya terdapat pengaruh dari variabel pemasaran pendidikan terhadap mutu pesantren.

\section{METODE}

Penelitian ini merupakan penelitian survei dengan menggunakan pendekatan kuantitatif. Variabel penelitian terdiri atas dua variabel yaitu variabel bebas $(\mathrm{X})$ dan variabel terikat $(\mathrm{Y})$ di mana variabel bebas $(\mathrm{X})$ adalah pemasaran pendidikan dan variabel terikat $(\mathrm{Y})$, yaitu mutu pesantren. Dengan metode yang digunakan, penelitian ini ditujukan untuk menemukan pengaruh variabel pemasaran pendidikan terhadap mutu pesantren.

Data penelitian ini terdiri atas data primer dan data sekunder. Data primer didapat melalui wawancara dan angket tentang pemasaran pendidikan dan mutu pesantren, sedangkan data sekunder diperoleh dengan studi dokumentasi, khususnya mengenai data strategi pemasaran di Pondok Pesantren Syamsul 'Ulum Sukabumi.

Populasi penelitian ini adalah seluruh pelanggan internal dan eksternal pesantren. Teknik cluster sampling digunakan untuk memilih responden yang terdiri dari santri, guru, pembimbing asrama, dan orang tua santri, dengan jumlah 220 orang. Teknik ini dipilih karena digunakan untuk mengkaji pengaruh pemasaran pendidikan terhadap mutu pesantren. Karena jumlah sampel keseluruhan 220 orang, maka masing-masing asrama putra dan putri diambil sejumlah 110 orang yang dijadikan responden. Pertimbangan dalam penentuan banyaknya sampel ini mendasarkan pada teknik analisis statistik yang digunakan. Analisis statistik yang digunakan pada penelitian ini adalah statistik parametrik. Jumlah sampel dan lokasi tersaji pada Tabel 1. 
Tabel 1. Jumlah Sampel

\begin{tabular}{clc}
\hline No & \multicolumn{1}{c}{ Status } & Jumlah Sampel \\
\hline 1 & Guru dan pembimbing Asrama Putra & 10 \\
2 & Santri Putra & 90 \\
3 & Orang Tua Santri Putra & 10 \\
4 & Guru dan Pembimbing Asrama Putri & 10 \\
5 & Santri Putri & 90 \\
6 & Orang Tua Santri Putri & 10 \\
\multicolumn{2}{c}{ Jumlah } \\
\hline
\end{tabular}

Teknik pengumpulan data dilakukan melalui wawancara, angket, dan dokumentasi. Wawancara dalam penelitian ini dilakukan untuk mendapatkan informasi awal mengenai permasalahan dan gambaran umum yang terjadi di lokasi penelitian. Penelitian ini menggunakan angket tertutup yang digunakan untuk menggali informasi mengenai variabel pemasaran pendidikan dan mutu pesantren. Selain itu, dokumentasi juga dilakukan untuk memperoleh data berkaitan dengan jumlah santri, guru, dan pembimbing asrama di Pondok Pesantren Syamsul 'Ulum Sukabumi.

Sebelum melakukan pengumpulan data dengan instrumen angket, instrumen yang telah disusun tersebut diuji cobakan terlebih dahulu kepada responden. Uji coba instrumen dilakukan di Pondok Pesantren Syamsul 'Ulum dengan 30 responden. Uji coba instrumen ini dimaksudkan untuk menguji validitas dan reliabilitas instrumen yang akan digunakan dalam penelitian. Uji validitas instrumen dilakukan melalui teknik korelasi product moment antara skor masing-masing butir dengan skor total (Azwar, 2011). Hasil perhitungan uji validitas dapat dikatakan valid jika rhitung > rtabel, sedangkan hasil uji reliabilitas dikatakan reliabel jika nilai Cronbach Alpha > 0,6 (Prayitno, 2010).

Setelah data terkumpul, selanjutnya dilakukan analisis data untuk mengetahui pengaruh antar variabel X terhadap Y, dengan pemasaran pendidikan sebagai variabel X (variabel bebas) dan mutu pesantren sebagai variabel Y (variabel terikat). Analisis data ini dilakukan dengan menggunakan teknik statistik parametrik melalui bantuan software SPSS 25.0. Statistik parametrik digunakan karena mengingat skala datanya rasio, dan data pada variabel terikat normal dan homogen. Berdasarkan alasan tersebut, maka untuk mencapai tujuan, penelitian ini menggunakan persamaan regresi linear sederhana sebagaimana disajikan pada Rumus (1) (Sugiyono, 2010).

$$
\mathrm{Y}=\mathrm{a}+\mathrm{bX}
$$

Analisis regresi linear sederhana digunakan untuk mengetahui arah hubungan dan pengaruh variabel pemasaran pendidikan sebagai variabel bebas (X) terhadap variabel mutu pesantren sebagai variabel terikat $(Y)$. Kriteria pengambilan keputusan dari hipotesis adalah apabila nilai $t_{\text {hitung }}<$ $\mathrm{t}_{\text {tabel}}$, maka H0 diterima, namun apabila nilai $\mathrm{t}_{\text {hitung }}>\mathrm{t}_{\text {tabel }}$, maka H0 ditolak (Priyatno, 2010).

\section{HASIL DAN PEMBAHASAN}

\section{Hasil}

Sebelum dilakukan penelitian, dilakukan uji instrumen dan uji persyaratan analisis. Dalam melakukan uji coba instrumen, peneliti menyebarkan angket kepada 30 santri, kemudian dilakukan perhitungan validitas dan reliabilitas dengan korelasi product moment melalui bantuan SPSS 25 . Berdasarkan perhitungan, seluruh item pada kuesioner dinyatakan valid karena nilai $r_{\text {hitung }}>r_{\text {tabel }}$ sehingga seluruh instrumen layak digunakan untuk pengukuran. Dalam mengumpulkan data penelitian dan hasil uji reliabilitas dari masing-masing kuesioner, diperoleh nilai Cronbach Alpha > 0,66, berarti instrumen yang digunakan dapat dipercaya dan diandalkan serta memberi hasil yang konsisten jika kuesioner digunakan kembali untuk meneliti obyek yang sama. Sementara itu, pengujian persyaratan analisis terdiri dari uji normalitas dan uji linearitas. Uji normalitas digunakan untuk membuktikan apakah data berdistribusi normal atau tidak menggunakan uji kolomogrov smirnov. Dengan nilai signifikansi sebesar 0,05 dan banyaknya $\mathrm{n}=30$, didapatkan hasil pada Tabel 2 . 
Tabel 2. Uji Normalitas

One-Sample Kolmogorov-Smirnov Test

\begin{tabular}{llr} 
& & Unstandardized Residual \\
\hline$N$ & & 30 \\
Normal Parameters ${ }^{a, b}$ & Mean & .0000000 \\
& Std. Deviation & 2.59187357 \\
Most Extreme Differences & Absolute & .100 \\
& Positive & .100 \\
& Negative & -.085 \\
Test Statistic & & .100 \\
Asymp. Sig. (2-tailed) & & $.200^{\mathrm{c}, \mathrm{d}}$ \\
\hline
\end{tabular}

Berdasarkan uji normalitas pada Tabel 2, diketahui nilai signifansi adalah 0,2 >0,05 artinya nilai residual berdistribusi normal, sehingga hasil analisis ini dapat lanjut ke analisis regresi, karena syarat dalam uji asumsi klasik nilai residualnya sudah terbukti berdistribusi normal. Sementara itu, uji linearitas digunakan untuk mengetahui apakah variabel dependent dan independent mempunyai hubungan yang linear atau tidak secara signifikan. Salah satu cara untuk mendeteksi ada atau tidaknya hubungan yang linear antar variabel ini adalah dengan menggunakan grafik scatter plot, sebagaimana disajikan dalam Gambar 2.

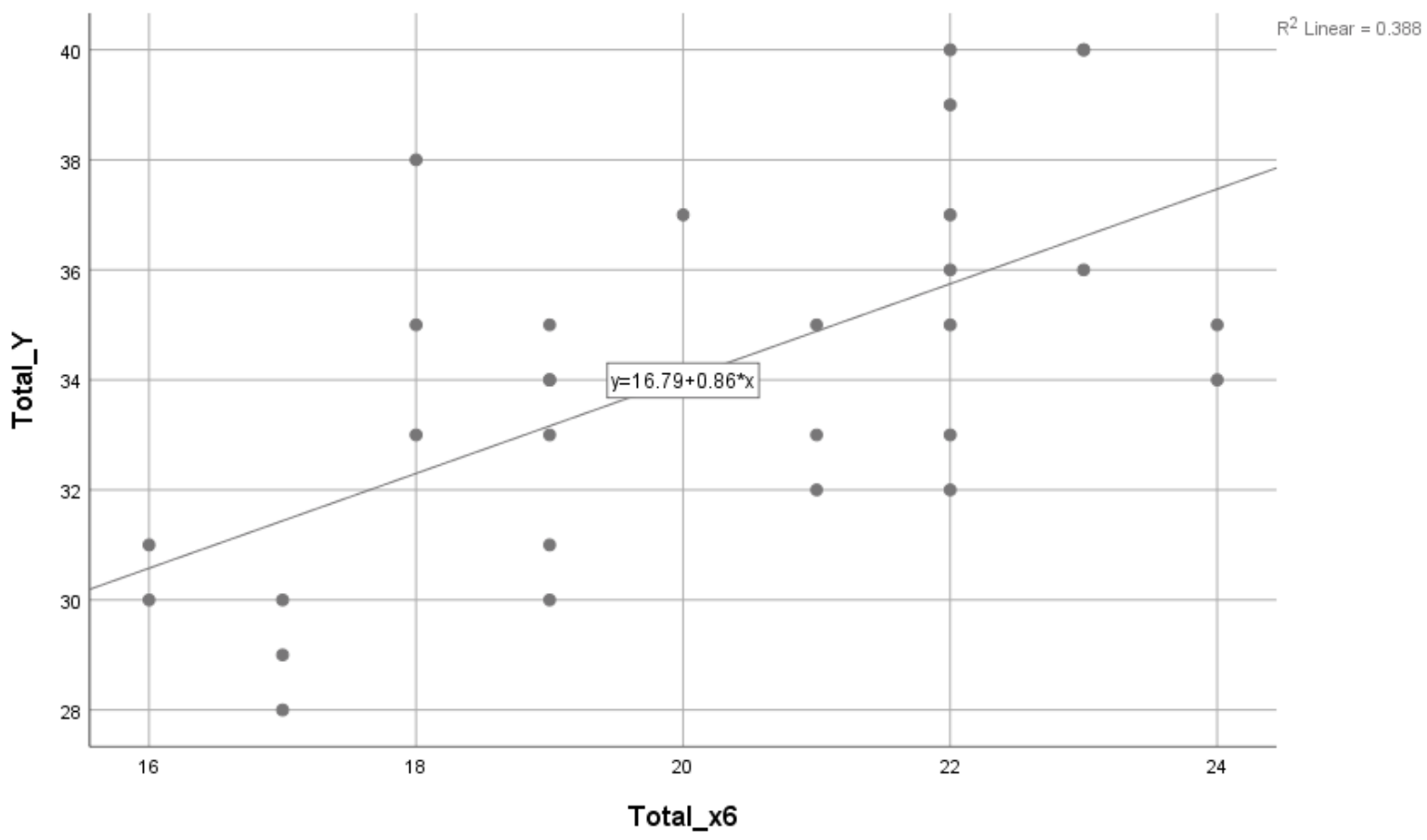

Gambar 2. Uji Linearitas Scatter Plot

Berdasarkan Gambar 2, terlihat titik-titik plot data membentuk pola garis lurus dari kiri bawah naik ke kanan atas, sehingga dapat disimpulkan terdapat hubungan yang linear dan positif antara variabel pemasaran pendidikan (X) dengan mutu pesantren (Y). Selanjutnya, dilakukan pengujian dengan analisis regresi sederhana, sebagaimana ditunjukkan pada Tabel 3.

Tabel 3. Hasil Analisis Regresi Sederhana

\begin{tabular}{|c|c|c|c|c|}
\hline \multicolumn{5}{|c|}{ Model Summary } \\
\hline Model & $R$ & $R$ Square & $\begin{array}{l}\text { Adjusted } R \\
\text { Square }\end{array}$ & $\begin{array}{l}\text { Std. Error of the } \\
\text { Estimate }\end{array}$ \\
\hline 1 & $.572^{\mathrm{a}}$ & .327 & .324 & 3.090 \\
\hline
\end{tabular}


Berdasarkan Tabel 3, besarnya nilai korelasi/hubungan (R) yaitu sebesar 0,572. Dari output tersebut juga diperoleh koefisien determinasi (R Square) sebesar 0,327 yang berarti pengaruh variabel pemasaran pendidikan (X) terhadap variabel mutu pesantren (Y) adalah sebesar $32,7 \%$.

Tabel 4. Perhitungan Persamaan Regresi Sederhana

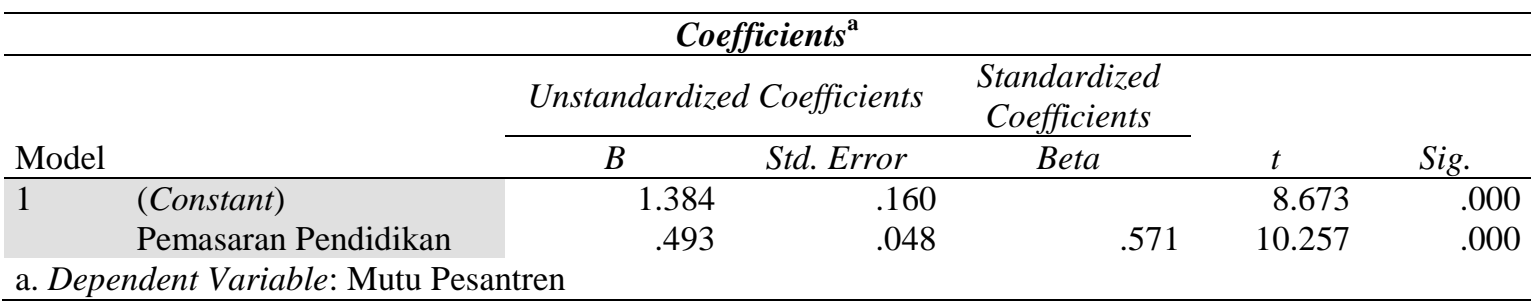

Dari data pada Tabel 4 dengan taraf signifikansi 0,05 dan $t_{\text {tabel }} 1,971$ diketahui hasil $t_{\text {hitung }}$ sebesar 10,257. Oleh karena $t_{\text {hitung }}>t_{\text {tabel }}(10,257>1,971)$, maka $H_{0}$ ditolak artinya terdapat pengaruh positif dan signifikan pemasaran pendidikan terhadap mutu Pondok Pesantren Syamsul 'Ulum. Pada Rumus (2) ditampilkan persamaan regresi linear sederhana, di mana $\mathrm{Y}=$ mutu pesantren, $\mathrm{a}=$ konstanta, $\mathrm{b}=$ koefisien regresi, dan $\mathrm{X}=$ pemasaran pendidikan.

$$
\mathrm{Y}=1,384+0,493 \mathrm{X} \ldots \ldots \ldots \ldots \ldots \ldots \text { (2) }
$$

Berdasarkan persamaan regresi linear sederhana pada Rumus (2), diketahui bahwa pemasaran pendidikan merupakan variabel independen $(\mathrm{X})$, sedangkan mutu pesantren merupakan variabel dependen (Y). Adapun nilai konstanta dan koefisien regresi variabel $\mathrm{X}$ masing-masing sebesar 1,384 dan 0, 493. Konstanta 1,384 yang artinya jika nilai pemasaran pendidikan 0 , maka nilai mutu pesantrennya 1,384. Koefisien regresi variabel pemasaran pendidikan sebesar 0,493. Artinya jika nilai pemasaran pendidikan mengalami kenaikan 1, maka mutu pesantren akan mengalami peningkatan sebesar 0,493. Koefisien bernilai positif menunjukkan bahwa terdapat hubungan positif antara pemasaran pendidikan dan mutu pesantren.

\section{Pembahasan}

Berdasarkan Tabel 3, diketahui nilai $\mathrm{R}$ sebesar 0,572 dan dapat diketahui bahwa variabel pemasaran pendidikan dengan mutu pesantren mempunyai korelasi yang kuat. Di sisi lain, nilai analisis koefisien determinasi diperoleh hasil pada $\mathrm{R}$ square sebesar 0,327 . Hal ini menunjukkan bahwa persentase sumbangan variabel pemasaran pendidikan terhadap mutu pesantren sebesar $32,7 \%$, jadi besarnya pengaruh pemasaran pendidikan terhadap mutu pesantren yaitu $32,7 \%$, sedangkan sisanya $67,4 \%$ dipengaruhi oleh faktor-faktor lain yang tidak diteliti dalam penelitian ini. Hal tersebut berarti bahwa pemasaran pendidikan memiliki pengaruh terhadap mutu pendidikan Pondok Pesantren Syamsul 'Ulum, sehingga apabila indikator-indikator pemasaran pendidikan di pesantren tersebut tinggi, maka mutu pesantren juga akan tinggi, sebaliknya jika indikator pemasaran pendidikan rendah, maka mutu pesantren akan rendah.

Hasil penelitian ini diperkuat dengan temuan Muadin (2017) bahwa manajemen pemasaran jasa pendidikan pesantren harus diterapkan untuk menciptakan budaya kualitas dalam setiap segmen dan langkahnya supaya jasa layanan pendidikan yang disiapkan benar-benar sesuai dengan kebutuhan sehingga menimbulkan kepuasan di kalangan masyarakat sebagai pengguna jasa pendidikan. Jika pengguna jasa pendidikan merasa puas dengan layanan jasa pendidikan yang diberikan, maka hal ini akan mengantarkan lembaga pondok pesantren pada citra yang lebih baik, citra lembaga yang baik akan meningkatkan peminat pendidikan (Munir, 2017), dan jika peminat pendidikan (pelanggan) meningkat maka pendapatan lembaga juga akan meningkat.

Mengingat produk yang dihasilkan pada bidang jasa sangat berbeda dengan produk dalam bentuk fisik, maka strategi pemasaran yang digunakan juga berbeda. Mudie dan Pirrie (2006) menjelaskan terdapat empat ciri utama pada layanan jasa yang sangat mempengaruhi rancangan program pemasaran, yaitu: (1) Intangibility (tidak berwujud). Jasa bersifat intangibility, artinya jasa ti- 
dak bisa dilihat, dirasa, dicium, didengar, atau diraba sebelum dibeli atau dikonsumsi. Dalam hal ini, pengguna jasa pendidikan hanya mendapat akses ke pendidikan, atau mendapatkan manfaat belajar dari layanan yang disediakan (Bado \& Nyangau, 2012). (2) Inseparability (tidak terpisahkan). Jasa bersifat inseparability, artinya, tidak dapat dipisahkan dari sumbernya, yaitu perusahaan yang menghasilkannya. (3) Variability (bervariasi). Jasa bersifat variability, artinya jasa yang diberikan sering kali berubah-ubah tergantung dari siapa yang menyajikannya, kapan, dan dimana penyajian jasa tersebut dilakukan. (4) Perishability (mudah musnah). Jasa bersifat perishability, artinya jasa tidak dapat disimpan atau mudah musnah sehingga tidak dapat dijual pada masa yang akan datang.

Meskipun pemasaran jasa pendidikan dirasa lebih sulit karena layanan pendidikan yang dipasarkan tidak berwujud, tidak dapat dipisahkan, dan tidak tahan lama, namun dalam hasil penelitiannya, Kalenskaya et al. (2013) menekankan pada dua hal, yaitu hubungan baru dalam ekonomi pendidikan dan penyediaan serta penawaran layanan jasa pendidikan. Tren pembangunan ekonomi dunia saat ini dengan ekonomi berbasis pengetahuan berimplikasi pada dunia pendidikan dengan meningkatnya tuntutan kualitas, relevansi, dan penerapan praktis produk dan layanan pendidikan. Oleh karena itu, menjadi sebuah keniscayaan bahwa penyediaan layanan jasa pendidikan menjadi komponen kunci untuk dapat memenuhi kebutuhan dan keinginan pengguna jasa pendidikan secara efektif, yang tidak kalah penting lagi adalah layanan jasa pendidikan ini juga perlu ditawarkan secara efektif dengan memahami perilaku populasi target dan kriteria yang mereka gunakan untuk menentukan pilihannya.

Berkaitan dengan pentingnya pemasaran pendidikan tersebut, manajemen pemasaran Pondok Pesantren Syamsul 'Ulum yang baik harus dimulai dengan mengevaluasi unsur-unsur pada bauran pemasaran (7P). Meskipun bauran pemasaran lebih popular di dunia bisnis, saat ini kegiatan layanan jasa pendidikan juga dapat menerapkannya, karena menurut Gajic (2012), penerapan bauran pemasaran di lembaga pendidikan dapat mengarahkan pada pencapaian keunggulan kompetitif di pasar pendidikan. Unsur-unsur bauran pemasaran pada penelitian ini dideskripsikan pada Tabel 5.

Tabel 5. Unsur-Unsur pada Bauran Pemasaran

\begin{tabular}{|c|c|c|}
\hline $\begin{array}{c}\text { Unsur Bauran } \\
\text { Pemasaran }\end{array}$ & Definisi & Bentuk Strategi \\
\hline Produk (Product) & $\begin{array}{l}\text { Segala sesuatu yang dapat ditawarkan } \\
\text { untuk memnuhi keinginan atau } \\
\text { kebutuhan masyarakat berupa barang } \\
\text { atau jasa }\end{array}$ & $\begin{array}{l}\text {-Mutu lulusan } \\
\text {-Program unggulan pesantren } \\
\text {-Kesesuaian program pendidikan }\end{array}$ \\
\hline Harga (Price) & $\begin{array}{l}\text { Sejumlah uang yang mempunyai nilai } \\
\text { tukar untuk memperoleh suatu barang } \\
\text { atau jasa. }\end{array}$ & $\begin{array}{l}\text {-Biaya Pendidikan } \\
\text {-Beasiswa } \\
\text {-Potongan harga khusus }\end{array}$ \\
\hline Tempat (Place) & $\begin{array}{l}\text { Lokasi dan aktivitas untuk } \\
\text { menyalurkan barang atau layanan } \\
\text { jasa bagi pelanggan }\end{array}$ & $\begin{array}{l}\text { - Lokasi pesantren } \\
\text { - Akses menuju lokasi } \\
\text {-Transportasi }\end{array}$ \\
\hline Promosi (Promotion) & $\begin{array}{l}\text { Semua kegiatan yang dilakukan } \\
\text { untuk mengomunikasikan dan } \\
\text { mempromosikan produk kepada } \\
\text { masayarakat }\end{array}$ & $\begin{array}{l}\text { - Strategi promosi pesantren } \\
\text { - Penyediaan informasi PSB } \\
\text { - Pemberdayaan alumni }\end{array}$ \\
\hline Orang (People) & $\begin{array}{l}\text { Aset utama penyedia barang atau } \\
\text { layanan jasa }\end{array}$ & $\begin{array}{l}\text { Kinerja pegawai dalam menyediakan } \\
\text { layanan jasa, baik dari tenaga pendidik/ } \\
\text { tenaga kependidikan }\end{array}$ \\
\hline Proses (Process) & $\begin{array}{l}\text { Prosedur, mekanisme dan aliran } \\
\text { aktivitas di mana produk barang atau } \\
\text { jasa disampaikan }\end{array}$ & $\begin{array}{l}\text {-Mutu Pembelajaran } \\
\text {-Metode pembelajaran yang digunakan } \\
\text {-Waktu tanggap keluhan dari orang } \\
\text { tua/masyarakat }\end{array}$ \\
\hline $\begin{array}{c}\text { Bukti Fisik (Physical } \\
\text { Evidence) }\end{array}$ & $\begin{array}{l}\text { Wujud nyata yang dimiliki oleh } \\
\text { penyedia barang atau jasa }\end{array}$ & $\begin{array}{l}\text {-Kondisi bangunan pesantren } \\
\text {-Fasilitas pesantren } \\
\text {-Suasana ruang belajar (kelas) }\end{array}$ \\
\hline
\end{tabular}

Sumber: Diolah kembali dari Kotler dan Keller (2008) 
Ketujuh unsur bauran pemasaran pada Tabel 5 dapat menjadi alat (tools) dalam melakukan analisis untuk menciptakan strategi pemasaran jasa pendidikan yang sesuai dengan potensi yang dimiliki Pondok Pesantren Syamsul 'Ulum, karena pada prinsipnya bauran pemasaran merupakan pengelolaan unsur-unsur bauran pemasaran agar dapat mempengaruhi orang pada keputusannya dalam pembelian produk (Azmi et al., 2015).

\section{SIMPULAN}

Berdasarkan hasil penelitian dan pembahasannya, pemasaran pendidikan berpengaruh positif dan siginifikan sebesar 32,6\% terhadap mutu Pondok Pesantren Syamsul 'Ulum. Oleh karena itu, dapat disimpulkan bahwa kegiatan pemasaran pendidikan akan meningkatkan mutu pesantren. Hal tersebut berimplikasi bahwa Pondok Pesantren Syamsul 'Ulum seyogyanya memberi perhatian serius pada kebutuhan pengguna jasa pendidikan dan jeli melihat segmentasi dan penentuan sasaran.

\section{UCAPAN TERIMA KASIH}

Peneliti mengucapkan terima kasih kepada semua responden dan narasumber yang berkontribusi atas waktu dan komitmen mereka untuk penelitian ini, juga kepada pihak Pondok Pesantren Syamsul 'Ulum yang telah mengizinkan peneliti untuk melakukan penelitian.

\section{DAFTAR PUSTAKA}

Ali, R. A., \& Fahrurrozi, F. (2006). Total quality management in education. IRCiSoD.

Azmi, M. F., Suharyono, S., \& Sunarti, S. (2015). Pengaruh bauran pemasaran terhadap keputusan pembelian (Survei pada mahasiswa yang menggunakan Notebook Asus di Universitas Brawijaya). Jurnal Administrasi Bisnis (JAB), 28(1), 175-184. Retrieved from http://administrasibisnis.studentjournal.ub.ac.id/index.php/jab/article/view/1143

Azwar, S. (2011). Reliabilitas dan validitas. Pustaka Pelajar.

Bado, N., \& Nyangau, J. (2012). Social media and marketing of higher education: A review of the literature. Journal of the Research Center for Educational Technology, 8(1), 38-51.

Bashori, B. (2017). Modernisasi lembaga pendidikan pesantren perspektif Azyumardi Azra. Nadwa: Jurnal Pendidikan Islam, 11(2), 269-295. https://doi.org/10.21580/nw.2017.11.2.1881

Gajic, J. (2012). Importance of marketing mix in higher education institutions. Singidunum Journal of Applied Sciences, 9(1), 29-41. https://doi.org/10.5937/sjas1201029G

Kalenskaya, N., Gafurov, I., \& Novenkova, A. (2013). Marketing of educational services: Research on service providers satisfaction. Procedia Economics and Finance, 5, 368-376. https://doi.org/10.1016/S2212-5671(13)00044-0

Khasanah, A. (2015). Pemasaran jasa pendidikan sebagai strategi peningkatan mutu di SD Alam Baturraden. Jurnal eL-Tarbawi, $\quad 8(2), \quad$ 161-176. https://doi.org/10.20885/tarbawi.vol8.iss2.art4

Kotler, P., \& Keller, K. L. (2008). Manajemen pemasaran (13 ${ }^{\text {th }}$ ed.) (B. Molan, trans.). Erlangga.

Muadin, A. (2017). Manajemen pemasaran pendidikan pondok pesantren Tahfidz Qur'an. TA'ALLUM: Jurnal Pendidikan Islam, 5(2), 293-308. https://doi.org/10.21274/taalum.2017.5.2.293-308

Mudie, P., \& Pirrie, A. (2006). Service marketing management. Elsevier.

Muhith, A. (2018). Quality culture of Islamic boarding school. International Journal of Research GRANTHAALAYAH, $6(10)$ 25-37. https://doi.org/10.29121/granthaalayah.v6.i10.2018.1158 
Munir, M. (2017). Manajemen pemasaran pendidikan dalam meningkatkan kuantitas peserta didik. INTIZAM: Jurnal Manajemen Pendidikan Islam, 1(2), 78-94. Retrieved from https://ejournal.staida-krempyang.ac.id/index.php/intizam/article/view/1

Mustaqiem, A. (2003). Menggagas pesantren transformatif. Majalah Aula, 27(9), 76.

Mustaqim, M. (2018). Analisis manajemen pemasaran jasa lembaga pendidikan Islam: Pondok Pesantren Amtsilati Darul Falah Bangsri Jepara. Nadwa: Jurnal Pendidikan Islam, 12(1), 117-128. https://doi.org/10.21580/nw.2018.12.1.2465

Prayitno, D. (2010). Paham analisa data statistik dengan SPSS. MediaKom.

Priyatno, D. (2010). Teknik mudah dan cepat melakukan analisis data penelitian dengan SPSS. Gava Media.

Rasmi, R. (2014). Peningkatan Mutu Dan Profil Lembaga Pendidikan dalam Perspektif Total Quality Management (TQM). Jurnal Al-Ta'dib, 7(1), 54-67. Retrieved from https://ejournal.iainkendari.ac.id/index.php/al-tadib/article/view/243

Sallis, E. (2007). Total quality management in education (Manajemen mutu pendidikan) (A. Riyadi, trans.). IRCISoD.

Siswanto, S. (2015). Desain mutu pendidikan pesantren. Jurnal Sosial dan Budaya Keislaman, 23(2), 258-274. Retrieved from http://ejournal.iainmadura.ac.id/index.php/karsa/article/view/726

Sugiyono, S. (2010). Metode penelitian pendidikan pendekatan kuantitatif, kualitatif, dan R\&D. Alfabeta.

Syarifah, L. S. (2019). Implementasi pendidikan karakter: Sebuah kajian ilmiah dari perspektif gaya kepemimpinan kepala sekolah. NIZAMUL 'ILMI: Jurnal Manajemen Pendidikan Islam, 4(1), 1-21. Retrieved from https://ejournal.staisyamsululum.ac.id/index.php/nizamulilmi/article/view/6

Syarifah, L. S. (2020a). Desain mutu pesantren berbasis total quality management (TQM). Nizamul 'Ilmi: Jurnal Manajemen Pendidikan Islam (JMPI), 5(1), 93-112. Retrieved from https://ejournal.staisyamsululum.ac.id/index.php/nizamulilmi/article/view/50

Syarifah, L. S. (2020b). Implementasi total quality management (TQM) di pesantren?. Jurnal at-Tadbir: Media Hukum dan Pendidikan, 30(1), 93112. Retrieved from https://ejournal.staisyamsululum.ac.id/index.php/attadbir/article/view/33 